\title{
Exploring the availability of Ontario's non-industrial private forest lands for recreation and forestry activities
}

\author{
by Len M. Hunt ${ }^{1}$
}

Privately owned forest lands contribute significant amounts of land for wood supply and recreational opportunities in various parts of Canada including areas within Ontario. The decisions that landowners make about permitting various activities on their lands can impact resource managers and current and potential users of forested environments. In this study, the willingness of Ontario's nonindustrial private forest landowners to conduct forest harvesting and to permit hunting and wildlife recreational opportunities is examined. The study explores whether the willingness of landowners with large-sized landholdings (i.e., minimum 20 ha) is influenced by characteristics that describe the private lands and the owners of these private lands. The results show that trends towards land parcelization, afforestation and loss of agricultural lands may impact the availability of lands for forest harvesting and hunting. The models also suggest that northern Ontario landowners may make different decisions about conducting forest harvesting or permitting hunting on their lands than do southern Ontario landowners.

Keywords: non-industrial private forest landowners, forest harvesting, hunting, wildlife viewing, land parcelization

Les forêts privées représentent des superficies importantes de territoires pour l'approvisionnement en bois et les possibilités d'activités récréatives dans diverses régions du Canada, y compris l'Ontario. Les décisions que les propriétaires prennent en permettant la tenue de diverses activités sur leurs terrains peuvent avoir un impact sur les aménagistes des ressources et sur les utilisateurs potentiels des environnements forestiers. Cette étude examine la volonté des propriétaires de boisés privés non-industriels de l'Ontario d'entreprendre des activités de récoltes de bois et de permettre la chasse et des activités récréatives touchant la faune. Cette étude cherche à savoir si cette volonté des propriétaires possédant de grandes superficies (par ex. un minimum de 20 ha) est influencée par les caractéristiques qui décrivent les forêts privées et les propriétaires de ces forêts privées. Les résultats indiquent que les tendances vers le morcellement des forêts, le déboisement et la perte de terres agricoles pourraient avoir un impact sur la disponibilité des forêts pour la récolte de bois et la chasse. Le modèle laisse entendre que les propriétaires du nord de l'Ontario semblent prendre des décisions différentes relativement à la réalisation de la récolte de bois ou au droit de chasse sur leurs forêts par rapport aux propriétaires du sud de l'Ontario.

Mots-clés : propriétaires de boisés privés non-industriels, récolte de bois, chasse, observation de la faune, morcellement du territoire

\section{Introduction}

The land use decisions made by non-industrial private forest (NIPF) landowners can seriously impact the resource management decisions of neighbouring landowners and public land managers and the use of forest lands by various individuals. These decisions made by NIPF landowners can range from permanently removing forested lands (i.e., urban or agricultural development) to protecting all forested resources from human use.

Of all possible land use decisions available to NIPF landowners, researchers have focused most attention on the decision to conduct forest harvesting on private lands. Researchers have examined this issue as either a dichotomous choice for conducting or delaying forest harvesting (Binkley 1981, Boyd 1984, Hyberg and Holthausen 1989, Kline et al. 2000, Prestemon and Wear 2000) or as an intensity measure of forest harvest on specific lands (Dennis 1989, Kuuluvainen and Salo 1991, Kuuluvainen et al. 1996). Additional efforts to understand wood supply issues have involved examinations of landowners' decisions to reforest their lands (Royer 1987, Hyberg and Holthausen 1989) and to employ forest stewardship plans (Tyson et al. 1998).

Most of the above studies have attempted to understand the behaviours of landowners from a utility rather than a profit-max-

\footnotetext{
${ }^{1}$ Centre for Northern Forest Ecosystem Research, Ontario Ministry of Nat ural Resources, 955 Oliver Rd., Thunder Bay, Ontario. E-mail: len.hunt@mnr.gov.on.ca
}

imization perspective. Binkley (1981) noted that past use of the profit-maximization model for understanding forest harvesting decisions of landowners has led to many instances of seemingly irrational behaviour by landowners. Therefore, he postulated that a utility maximization framework better explains the forest harvesting decisions by NIPF landowners. By employing this utility framework, the importance of the

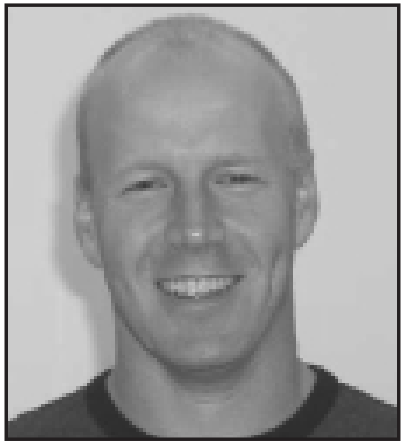

Len M. Hunt profit maximization motive to a landowner for deciding whether or not to harvest forested lands is tempered by the many benefits that an individual accrues from his/her forested environments. As such, this decision framework fits well with the paradigms of multiple use planning and integrated resource management.

Despite the emphasis of past research on the forest harvesting decisions of NIPF landowners, there are still many other choices available to NIPF landowners that may impact the enjoyment people receive from forested environments. The decision to provide recreational opportunities is one of these additional choices that has received only scant attention from past research (e.g., Wright et al. 1988). Clearly, the decision of private landowners to permit recreational activities on their lands 
may impact the pursuit of a recreational activity by interested individuals.

Two very different recreational activities that landowners can permit on their lands are hunting and wildlife viewing. The amount of setting opportunities available for hunters may be very limited in areas where private forest lands dominate. It is possible that the decisions by NIPF landowners to restrict hunting activities on their lands may create shortages of suitable recreational areas for hunters. Consequently, losses to areas for hunting may lower hunter participation but increase congestion among the remaining hunters and conflict between hunters and other forest users in the remaining areas available for recreational pursuits.

Compared to forest harvesting and hunting, the decision to permit wildlife viewing should be less demanding on owners, and possibly it may involve a lower risk of liability. The fact that these non-consumptive recreationists consume no private land resources leads one to believe that few NIPF landowners would restrict these activities. However, a survey from 1986 found that landowners from the United States were equally, if not more, likely to permit hunting as they were to permit photography, bird watching and nature study activities on their lands (Wright et al. 1990). With expected increasing demands for non-consumptive recreational activities, it is likely that many recreationists will ask private landowners to provide their lands for these activities. Therefore, an analysis of the decisions of landowners to permit these non-consumptive activities may provide important information to individuals tasked with resource and recreational planning responsibilities.

This study examines the willingness of NIPF landowners of Ontario with large landholdings (i.e., minimum of $20 \mathrm{ha}$ ) to consider permitting forest harvesting, recreational hunting and wildlife viewing activities on their lands. By examining considerations rather than actual behaviour, this study is able to provide information related to the potential availability of lands for recreation and forest harvesting. The potential availability of lands for these activities may be of more importance to resource managers than the actual use of the lands for these activities.

The paper is exploratory in purpose, and it is provided to increase interest in examining issues related to NIPF lands and landowners in Ontario and Canada. The remainder of this section discusses the choice of variables employed to analyze the willingness of landowners to consider permitting these activities on their lands.

Past research on the decisions of NIPF landowners to harvest forests supports the selection of independent variables used in this study. Many researchers (Thompson and Jones 1981, Boyd 1984, Hyberg and Holthausen 1989, Kuuluvainen and Salo 1991, Kline et al. 2000) have shown that the size of the landholdings is an important factor for explaining forest harvesting decisions by landowners. These studies showed that the decision to harvest forest land was positively related to the size of landholdings of an NIPF landowner. Consequently, increasing land parcelization ${ }^{2}$ may negatively impact wood supply. If land parcelization increases in Ontario, it may also impact the decisions of landowners to permit recreational activities. Therefore, the amount of landholdings was included as an independent variable in all analyses.

${ }^{2}$ Land parcelization refers to divisions of land into smaller administrative holdings. For private lands, parcelization occurs when owners of lands sever or subdivide their properties.
Past research also has demonstrated a relationship between the amount of forested lands and NIPF landowners' decisions to harvest forested lands (Binkley 1981, Hyberg and Holthausen 1989) and to permit recreational hunting (Wright et al. 1988). For forest harvesting decisions, landowners who held greater amounts of forested lands were more likely to conduct forest harvesting than were other landowners. To reduce the collinearity between amount of forested area and the size of landholdings, the amount of forested lands was transformed into a variable measuring the proportion of land that was forested. This variable was included in all analyses to determine, in part, whether afforestation efforts may impact the supply of timber and recreational opportunities.

Some researchers have investigated whether the decision of a landowner to conduct forest harvesting differs for farmers and non-farmers (Ontario Ministry of Natural Resources no date, Binkley 1981, Boyd 1984, Hyberg and Holthausen 1989, Kuuluvainen and Salo 1991). Although Kuuluvainen and Salo (1991) found no differences between the forest intensity rates of these groups, other studies typically have found that farmers were more apt to harvest their lands than were non-farmers. Binkley (1981) speculated that this finding arose since farmers were already earning income from their land. The farming variable and the interaction of the farming variable and land characteristics were included in all analyses.

The age of the landowner was included in all analyses since many researchers have found that age was negatively linked to the decisions of landowners to harvest forest lands (Kuuluvainen and Salo 1991, Kuuluvainen et al.1996, Kline et al. 2000) and to permit hunting (Wright et al. 1988). Kuuluvainen et al. (1996) suggested that this negative relationship between forest harvesting decisions and age related to the life cycle model. To determine whether changes to the average ages of landowners may impact the supply of timber and recreational opportunities, age was included as a variable in all analyses.

Land residency (i.e., whether owners lived on their properties or not) was included as an explanatory factor despite being absent from most previous studies. As exceptions, Wright et al. (1988) found no significant effect from residency on the hunting access restrictions selected by landowners, and Boyd (1984) found only a weak negative relationship between the distance a landowner lived from his/her private land and the decision to conduct forest harvesting. This variable was included to test whether increases or decreases to the number of absentee landowners may impact the future availability of wood supply or recreational opportunities.

Finally, the region where the private lands are located was included in the analyses. The regional variable separated southern and northern Ontario landowners. This variable was introduced since southern Ontario forested lands are dominated by private land forests while northern Ontario forested lands are dominated by public forest lands. Brunson et al. (1996) suggested that the proximity of private lands to large tracts of public forest land might influence a landowner's decision to permit or to prohibit certain activities on his/her land. As well, the inclusion of a regional variable may capture important regional value differences for forest products (e.g., the different forest composition between northern and southern Ontario forests) and recreational demands (i.e., the potential to extract use payment from recreationists). 
Several other potentially important variables identified by past researchers were not available for this study. These omitted variables include biophysical measures of the private forested lands, proximity of land properties to transportation networks and the wealth, income, land management objectives and management program awareness level of landowners. Additionally, no information related to prices for wood, reforestation costs, or interest rates were employed for the analyses. Readers are warned that the omission of these possible explanatory factors may impact the analyses and the conclusions drawn from these analyses.

Despite these omissions, this study provides an important contribution to research on NIPF landowners. First, few studies (Salkie et al. 1995, Wellstead et al. 1999) have formally examined possible activity decisions made by Canadian landowners. It is possible that the decisions made by Canadian landowners might differ from the decisions made by their American and European cousins. Second, unlike most previous model formulations ${ }^{3}$, this study tests whether the inclusion of quadratic relationships provide additional insights into the possible activity decisions of NIPF landowners than do linear models. Third, the models here test whether the possible activity decisions made by landowners differ on a regional basis. Finally, this study investigates the willingness of landowners to consider permitting forest harvesting and other recreational activities on their lands, which has been absent from past research efforts.

\section{Methods}

A survey by Environics (2000) of NIPF landowners in Ontario provided the data for this study. The survey instrument was conducted in April and May of 2000 with private landowners from Ontario who held large private landholdings. Although efforts were made to avoid duplication, it was possible that individuals who held more than one property could have had greater chances of being selected in the sample.

For respondents from southern Ontario, an owner was considered to have large landholdings when his/her property equaled or exceeded approximately 10 ha. For northern Ontario respondents, the minimum size for a large landholding was approximately 20 ha.

The survey was administered by telephone to a random sample of landowners identified from property tax assessment roles. Of the 3371 contacts made with qualified landowners (i.e., they fit the criteria above), 1215 respondents completed the telephone survey (36.0\%. response rate). No adjustments were made to account for potential non-response bias.

The survey was designed to provide multifaceted information about private landowners in Ontario. The wide range of partners involved in the surveys provided only an opportunity to collect exploratory information that was used to create profiles of Ontario landowners. Although the analyses here focus on a very specific issue, the reader is forewarned that the data were not collected specifically for the development of these explanatory models.

The survey data collection employed a random stratified sampling approach. The strata of interest were eight sub-regions in Ontario where it was known that a simple random sample of landowners would not provide sufficient sample sizes for

${ }^{3}$ For an exception, see Dennis (1990). all sub-regions of interest. To mitigate this potential bias, the results were weighted by this stratified sampling approach.

Regression analyses examine whether the willingness of landowners to consider permitting various activities was related to characteristics of landowners and their lands. In all cases, the dependent variable was a dichotomous choice of whether or not the landowner would consider permitting the activity. Therefore, probit regression models were used to analyze these dichotomous considerations.

\section{Results}

An overview of private forest lands in Ontario is provided before examining the results of predictive models. Fig. 1 shows the boundary used by this study to delineate northern and southern Ontario. This boundary used by this study is much further south than the boundary that separates the southern from the two northern administrative regions of the Ontario Ministry of Natural Resources (OMNR). However, the area in between the two boundaries (i.e., the Algonquin area) has a substantial amount of Crown lands that make this area more like the remaining northern than southern Ontario region.

The results in Table 1 show the patterns of land distribution between northern and southern Ontario as defined by the OMNR administrative regions. Although these numbers are not directly comparable to the regions used in this study, the table does demonstrate the basic differences between the two regions. In fact, Table 1 underestimates the importance of private land forests for the southern Ontario region used by this study.

Table 1 shows the distribution of forested lands in Ontario by ownership type. The table shows that the Crown (i.e., the public lands held by the province) owns a large percentage (92\%) of productive forested lands in northern Ontario. Although accounting for only $6.9 \%$ of productive forest lands in northern Ontario, private owners do hold lands that have almost 2.5 million hectares. In southern Ontario, privately held lands account for almost two-thirds of productive forest. These lands account for a total that exceeds 3.3 million hectares. Crown lands account for slightly over one-third of productive forests in southern Ontario.

The distribution of the private landholdings in southern and northern Ontario is not evenly distributed. In northern Ontario, non-industrial private land forests are important in areas around the larger urban areas of northern Ontario (e.g., Thunder Bay, Sudbury, Sault Ste. Marie and North Bay) and in a few other areas. In southern Ontario, Crown forests are almost nonexistent as one moves to the southeast and southwest areas of the province.

The sample used for the description of variables was 847 individuals of the 1215 individuals that responded to the questionnaires conducted by Environics. Several reasons led to the reduction from the original sample size. First, landowners were required to have properties that were at least twenty hectares in size along with at least one forested hectare. This reduction was necessary to account for the different selection methods used by Environics to sample southern and northern Ontario landowners. Second, individuals were required to provide complete information related to age, residency and occupation characteristics. Finally, one respondent who owned 5000 ha of land was removed from the analyses because this individual's landholdings were over two times greater than were the landholdings for any other respondent. 


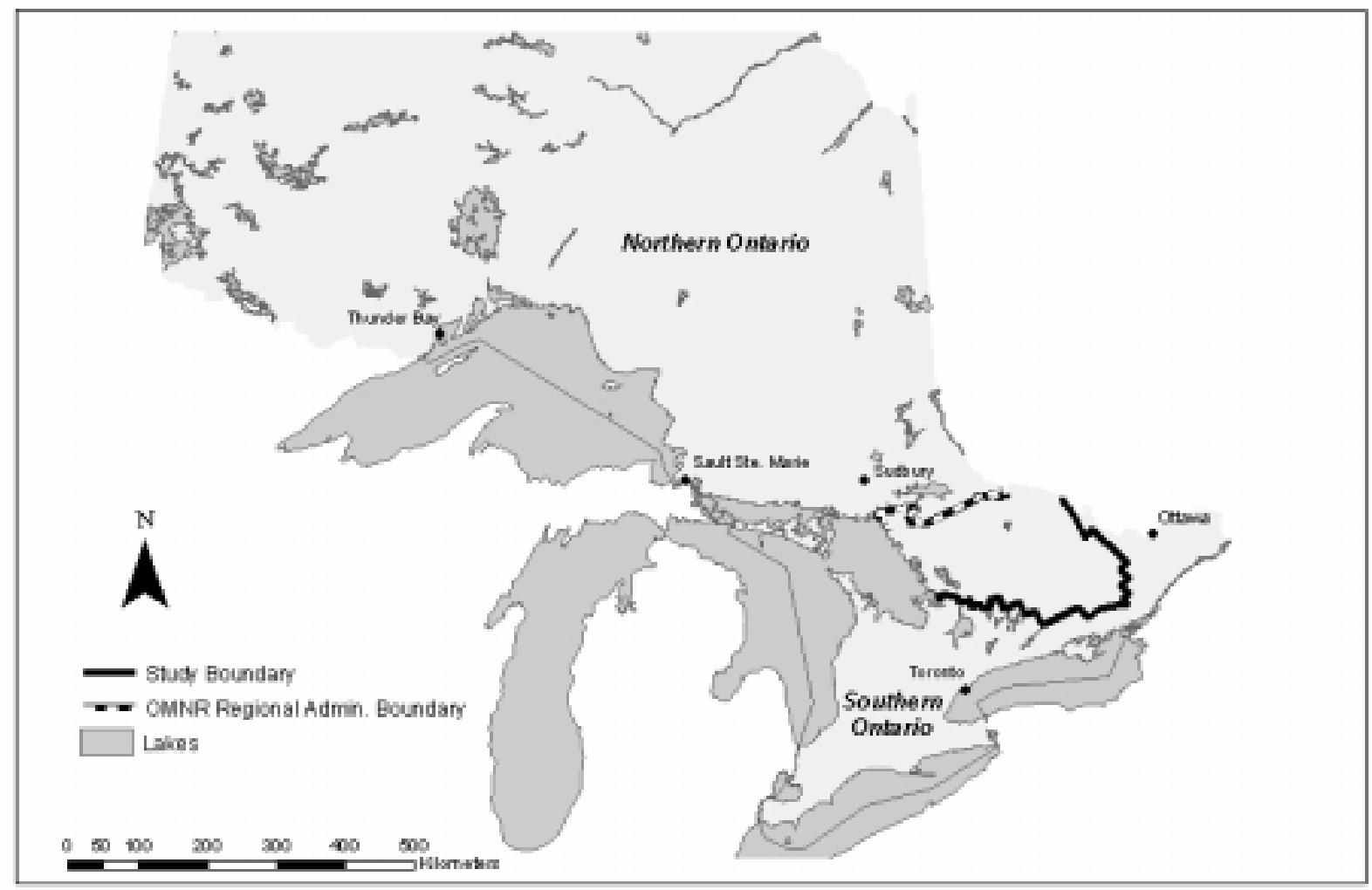

Fig. 1. Boundaries separating northern and southern Ontario regions.

Table 1. Distribution of forested lands in Ontario

\begin{tabular}{lrcccc}
\hline & \multicolumn{2}{c}{ Northern Ontario } & & \multicolumn{2}{c}{ Southern Ontario } \\
\cline { 2 - 3 } \cline { 5 - 6 } & $\begin{array}{c}\text { Amount } \\
\text { (000s ha) }\end{array}$ & Percentage & & $\begin{array}{c}\text { Amount } \\
\text { (000s ha) }\end{array}$ & Percentage \\
\hline Crown Lands & 32280.2 & 92.0 & & 1859.3 & 35.6 \\
Private Lands & 2416.5 & 6.9 & & 3347.6 & 64.1 \\
Federal Lands & 386.5 & 1.1 & & 12.4 & 0.2 \\
Total Lands & 35083.2 & & & 5219.3 & \\
\hline
\end{tabular}

After: Table 1, Ontario Ministry of Natural Resources (2000)

Table 2 describes the sample means, standard deviations, minimums and maximums for the selected variables for the sampled respondents. Although the results were weighted to account for the known bias in sub-regional data collection, readers are cautioned that the results in this table have not been adjusted to account for a possible bias in the distribution of landholding sizes.

The first three items in Table 2 were employed as dependent variables in the probit model. Specifically, the survey asked individuals which of these (among other) activities would they consider allowing on their property. No distinction was made between personal and any other use of lands. About one-half of the respondents stated that they would consider allowing harvesting and hunting on their properties. By contrast, about twothirds of the sampled landowners would consider permitting wildlife viewing on their lands. This fact seems to support the tenet that NIPF landowners should be more willing to permit non-consumptive activities, such as wildlife viewing, than consumptive activities, such as hunting and forest harvesting.
The sampled landowners had an average landholding of about 92 ha. Forests would typically cover one-third of these lands. The landowners tended to be mature (i.e., an average age of about 54 years). Over two-fifths of the landowners categorized themselves as farmers and over four-fifths of these individuals resided on their private lands. Finally, only about one-quarter of the landowners were from northern Ontario.

Each probit regression model employed the identical set of independent variables. The independent variables consisted of indicator variables that measured region of residence, whether or not an individual was a farmer, and the residence of the landowner. These indicator variables were effects coded (i.e., +1 and -1 ) to limit collinearity between these variables and the intercept term. The remaining independent variables included the age of the respondent, the size of the private lands and the proportion of forested lands. Each of these variables was centred to a mean of zero. This centring permits quadratic terms to be used in the model while minimizing the linear correlation of the quadratic and linear term (Fox 1984). The centering also assists in reducing scale effects that can arise when interactions are considered. Several other variables were included that interacted the land characteristics with the farming and regional variables.

Table 3 displays the parameter estimates and standard errors from the probit regressions based on the willingness of landowners to consider allowing forest harvesting, hunting, and wildlife viewing on their lands. The likelihood ratio test, on the restricted model, presented at the bottom of the table examines whether the parameter estimates are all equal to zero (i.e., the model provides no explanatory power). 


\begin{tabular}{|c|c|c|c|c|c|}
\hline & Mean & $\begin{array}{l}\text { Standard } \\
\text { Deviation }\end{array}$ & Minimum & Maximum & $\mathbf{n}$ \\
\hline Landowners who consider permitting forest harvesting (\%) & 50.02 & NA & NA & NA & 752 \\
\hline Landowners who consider permitting hunting $(\%)$ & 53.91 & NA & NA & NA & 782 \\
\hline Landowners who consider permitting wildlife viewing (\%) & 65.58 & NA & NA & NA & 785 \\
\hline Size of landholdings (hectares) & 92.52 & 137.69 & 20.23 & 2339.00 & 847 \\
\hline Forested area $(\%)$ & 35.88 & 30.82 & 0.40 & 100.00 & 847 \\
\hline Age of landowners & 53.79 & 13.40 & 20.00 & 91.00 & 847 \\
\hline Landowners residing on their lands (\%) & 82.36 & NA & NA & NA & 847 \\
\hline Farming landowners $(\%)$ & 41.91 & NA & NA & NA & 847 \\
\hline Northern Ontario landowners (\%) & 26.96 & NA & NA & NA & 847 \\
\hline
\end{tabular}

Table 3. Parameter estimates from probit regression models (standard errors in parentheses)

\begin{tabular}{|c|c|c|c|}
\hline & Forest Harvesting & Hunting & Wildlife Viewing \\
\hline Intercept & $\begin{array}{c}0.0312 \\
(0.0948)\end{array}$ & $\begin{array}{c}0.0348 \\
(0.1033)\end{array}$ & $\begin{array}{rl}* * & 0.4531 \\
(0.0812)\end{array}$ \\
\hline Region $(1=$ Northern $O N,-1=$ Southern $O N)$ & $\begin{array}{r}* *-0.1399 \\
(0.0625)\end{array}$ & $\begin{array}{r}* *-0.2342 \\
(0.0731)\end{array}$ & $\begin{array}{c}0.0005 \\
(0.0589)\end{array}$ \\
\hline Farm $(1=$ yes, $-1=n o)$ & $\begin{array}{c}0.0548 \\
(0.0631)\end{array}$ & $\begin{array}{r}* 0.1163 \\
(0.0632)\end{array}$ & $\begin{array}{c}-0.0234 \\
(0.0525)\end{array}$ \\
\hline Residence ( $1=$ on private land, $-1=$ elsewhere $)$ & $\begin{array}{c}0.0244 \\
(0.0736)\end{array}$ & $\begin{array}{c}0.0105 \\
(0.0700)\end{array}$ & $\begin{array}{c}-0.0936 \\
(0.0667)\end{array}$ \\
\hline Landholding Size in ha (linear) & $\begin{array}{r}5.902 \mathrm{e}-05 \\
(15.20 \mathrm{e}-05)\end{array}$ & $\begin{array}{c}43.05 \mathrm{e}-05 \\
(14.32 \mathrm{e}-05)\end{array}$ & $\begin{array}{l}-0.3312 \mathrm{e}-05 \\
(12.34 \mathrm{e}-05)\end{array}$ \\
\hline Landholding Size in ha (quadratic) & $\begin{array}{c}61.76 \mathrm{e}-08 \\
(36.67 \mathrm{e}-08)\end{array}$ & $\begin{array}{c}-6.142 \mathrm{e}-08 \\
(11.91 \mathrm{e}-08)\end{array}$ & $\begin{array}{c}5.341 \mathrm{e}-08 \\
(8.082 \mathrm{e}-08)\end{array}$ \\
\hline Age of Land Owner (linear) & $\begin{array}{c}-0.0006 \\
(0.0036)\end{array}$ & $\begin{array}{l}-0.0025 \\
(0.0035)\end{array}$ & $\begin{array}{l}0.0016 \\
(0.0034)\end{array}$ \\
\hline Age of Land Owner (quadratic) & $\begin{array}{r}* *-0.0009 \\
(0.0002)\end{array}$ & $\begin{array}{c}-0.0003 \\
(0.0002)\end{array}$ & $\begin{array}{c}0.0001 \\
(0.0002)\end{array}$ \\
\hline Proportion of landholding that is forested (linear) & $\begin{array}{c}0.2802 \\
(0.2292)\end{array}$ & $\begin{array}{c}0.3930 \\
(0.2490)\end{array}$ & $\begin{array}{c}0.2888 \\
(0.1851)\end{array}$ \\
\hline Farm * landholding in ha (linear) & $\begin{array}{c}*-25.29 \mathrm{e}-05 \\
\quad(15.05 \mathrm{e}-05)\end{array}$ & $\begin{array}{r}* *-31.98 \mathrm{e}-05 \\
\quad(15.11 \mathrm{e}-05)\end{array}$ & NA \\
\hline Farm * landholding in ha (quadratic) & $\begin{array}{c}* 71.38 \mathrm{e}-08 \\
\quad(36.62 \mathrm{e}-08)\end{array}$ & $\begin{array}{r}* * 36.75 \mathrm{e}-08 \\
\quad(16.73 \mathrm{e}-08)\end{array}$ & NA \\
\hline Farm * forested proportion of landholding (linear) & $\begin{array}{r}* *-0.4304 \\
(0.2052)\end{array}$ & $\begin{array}{c}0.0331 \\
(0.2180)\end{array}$ & NA \\
\hline Region * landholding in ha (linear) & NA & $\begin{array}{c}-12.40 \mathrm{e}-05 \\
(15.24 \mathrm{e}-05)\end{array}$ & NA \\
\hline Region * landholding in ha (quadratic) & NA & $\begin{array}{r}* * 26.90 \mathrm{e}-08 \\
\quad(13.59 \mathrm{e}-08)\end{array}$ & NA \\
\hline Region $*$ forested proportion of landholding (linear) & NA & $\begin{array}{c}* * 0.6815 \\
(0.2020)\end{array}$ & NA \\
\hline Log Likelihood (restricted model, B=0) & -552.6354 & -539.8882 & -505.2418 \\
\hline Log Likelihood (unrestricted model) & -521.2227 & -507.9341 & -499.3927 \\
\hline Likelihood ratio (LR) test on restricted model & $<0.0001$ & $<0.0001$ & 0.2309 \\
\hline LR test (farm interactions $=0$ ) & 0.0156 & 0.0903 & 0.4328 \\
\hline LR test (region interactions $=0$ ) & 0.1930 & 0.0005 & 0.3498 \\
\hline Rho Squared & 0.0568 & 0.0592 & 0.0116 \\
\hline
\end{tabular}

* statistically significant difference from zero $(\mathrm{p}<0.10)$

*** statistically significant difference from zero $(\mathrm{p}<0.05)$

The models that explain the willingness of landowners to consider permitting hunting and forest harvesting were significantly different from zero. However, the likelihood ratio test for the wildlife viewing model could not statistically conclude that the parameter estimates were different from zero. In fact, Table 3 shows that only the intercept term appeared to be related to landowners' decisions to consider permitting wildlife viewing on their lands. This positive value for the intercept suggested that the majority of landowners might permit wildlife viewing on their lands. As such, the model is completely incapable of explaining the reasons that individuals may have for restricting wildlife viewing on their properties.
The model parameter estimates in Table 3 are best viewed as changes to standardized scores (i.e., z-scores). Therefore, the change in the probability that an individual would allow a certain activity is contingent not only upon the change in a parameter estimate, but also the starting point for the comparison.

The forest harvesting model provides some insights into landowner and land characteristics that help to explain whether landowners would consider allowing forest harvesting on their lands. The non-significant intercept value arises from the nearly equal split of respondents that would or would not consider allowing forest harvesting on their lands. The significant and negative parameter estimate for the regional variable sug- 
gests that landowners from northern Ontario were less inclined to consider permitting forest harvesting on their lands than were the southern Ontario landowners. A likelihood ratio test suggested that the interactions between land characteristics and region of residence were not significantly different from zero.

The linear and quadratic estimates for the landholding size and the farming variable parameter estimate were not significantly different from zero. However, these parameters were retained in the model since the interactions between farming and the linear and quadratic terms for landholdings were significantly different from zero at a $90 \%$ confidence level. The model predicts that non-farmers were more likely to consider allowing forest harvesting on large than small-sized landholdings, albeit at a diminishing rate. The model also predicts that farmers with landholdings of about 175 ha were least likely to consider allowing forest harvesting. Despite these relationships, the model predicts that while holding proportion of forested land constant, farmers were more likely to consider harvesting their lands than were non-farmers for any reasonable-sized landholding.

The linear estimate for age was not significantly different from zero. However, the significant quadratic estimate for age suggested that the relationship of age and the decision to permit forest harvesting on lands was non-linear. The relationship suggested that 55-year-old landowners were most likely to allow harvesting on their lands. The relative impact of increasing age on this decision, however, was greater for individuals who were very much younger or older than 55 years of age.

Although the parameter estimate for proportion of forested land was not statistically different from zero, it was retained because the parameter estimate for the interaction between farming and proportion of forested land was statistically different from zero. The model predicts that increasing proportions of forested lands had a positive effect on the considerations of non-farmers and a negative effect on the considerations of farmers to allow forest harvesting on their lands. Although this negative effect was unexpected, it may arise because farmers who have already cleared some of their forested lands may be more willing to clear additional lands than would other farmers.

The model that explained the willingness of landowners to allow hunting on their lands provided some important findings. The non-significant estimate for the intercept arose because there was an almost equal number of landowners who would and would not consider permitting hunting on their lands. The parameter estimates for age and residency were also not significantly different from zero. The significant regional and farm parameter estimates suggested, ceteris paribus, that landowners from southern Ontario and farming landowners were more likely to permit hunting on their lands than were their counterparts.

The impact of landholding size on landowners' willingness to consider permitting hunting on private lands was influenced by the residency and farming orientation of the landowner. For southern Ontario farmers and non-farmers and northern Ontario non-farmers, the model predicted that increasing landholdings were positively related to the willingness to permit hunting on their lands. The model also predicted that northern Ontario farmers who had landholdings of 100 ha were less likely to consider permitting hunting on their lands than were other northern Ontario farmers. Over all sizes of landholdings, the model predicted that southern Ontario farmers were most likely to consider permitting hunting on their lands followed by southern Ontario non-farmers, ceteris paribus.

The regional residence of the landowner influenced the effect of the proportion of forested landholdings on a landowner's willingness to consider permitting hunting. The model predicted a positive relationship between the proportion of forested lands and the probability that northern Ontario landowners would permit hunting. The model predicted a negative relationship between the proportion of forested lands and the probability that southern Ontario landowners would permit hunting. Up until the forested percentage of lands reaches over $70 \%$, the model predicted that southern Ontario farmers would be most willing to consider permitting hunting on their lands, ceteris paribus. Above $70 \%$ forested land, the model predicted that northern Ontario farmers would be most willing to consider permitting hunting on their lands, ceteris paribus.

\section{Discussion}

Past research on the decisions of landowners to permit various activities on their private lands has normally focused on the decisions of American landowners. A smaller amount of information is available for European and Canadian landowners. In fact, research on Ontario NIPF landowners (Ontario Ministry of Natural Resources no date; Smyth and Nausedas 1982; Factor Research Group 1995; Environics Research Group 2000, 2001) has primarily profiled these individuals. Although these profiles provide important information for decision-makers, this study demonstrates that research can provide predictive information about possible behavioural choices made by landowners.

This study provided evidence that the willingness of landowners with large-sized landholdings to consider allowing forest harvesting and hunting on their lands were partially explainable by characteristics of the private lands and the landowners. The willingness of landowners to consider permitting wildlife viewing on their lands, however, was not at all explainable by these same factors.

One real concern among the holdings of private lands relates to the parcelization of the lands. Parcelization inevitably occurs when landowners divide and subdivide their properties for a variety of reasons. While the amount of land stays constant, the number of landowners increases. Many researchers have suggested that parcelization of lands may cause problems for wood supply from private lands (e.g., Row 1978, Thompson and Jones 1981, DeCoster 1998). The parcelization of private lands may also affect the amount of land available for recreational activities such as hunting.

Past researchers have primarily found a positive impact between landholding size and the decisions of landowners to conduct forest harvesting (Binkley, 1981, Thompson and Jones 1981, Boyd 1984, Hyberg and Holthausen 1989, Kuuluvainen and Salo 1991, Kline et al. 2000) and to permit hunting (Wright et al. 1988) on their private lands. Although the results of this study generally support this positive relationship, the occupancy and, in the case of hunting, the residence location of the landowner mediated the effects of landholding size. The inclusion of significant quadratic estimates also suggests that the relationship between landholding size and the decisions to consider permitting forest harvesting and hunting maybe more complex than suggested by previous research. Furthermore, the models predicted that some groups 
might not follow this expected positive relationship between size of landholdings and willingness to consider conducting forest harvesting (e.g., farmers).

Afforestation is another emerging issue for private lands. There is increasing interest in the role that afforestation efforts can have in acting as carbon sinks to reduce green house gas emissions (see Article 3.3; United Nations Framework Convention on Climate Change 1997). As such, there is a need to understand whether afforestation efforts are likely to impact wood supply and recreational hunting opportunities. For willingness to permit forest harvesting, the significant interaction between farming and proportion of forested land suggests that the proportion of forested property positively impacted nonfarming landowners and negatively impacted farming Ontario landowners. This negative relationship was hypothesized to arise from the continued willingness of farmers to clear additional lands for forest harvesting in the future. The proportion of forested land had a positive effect on the willingness of northern Ontario landowners to consider permitting hunting on their lands. However, forested lands had a negative effect on the willingness of southern Ontario landowners to consider permitting hunting on their properties.

From 1969 to 1981, the percentage of private landowners in Ontario that were farmers declined (Smyth and Nausedas 1982). Given this possible trend, it is important to determine whether farmers and non-farmers differ in their propensity to allow forest harvesting and/or recreational activities on their lands. This study generally supports past research findings that farmers were more likely to consider harvesting forests on their lands than were non-farmers. As well, this study suggested that farmers were more likely to consider permitting hunting on their lands than were non-farming landowners. Consequently, a relative loss in the proportion of NIPF lands owned by farmers may reduce wood supply and restrict hunting opportunities.

The location of private lands in relation to the abundance of public lands may influence a landowner's willingness to consider permitting recreational activities. Unlike past research from the United States (Brunson et al. 1996), this study found that landowners who owned properties in areas dominated by public lands were less likely to consider conducting forest harvesting and permitting hunting than were other landowners. However, these results may be attributable to market forces that lead to higher economic returns for forest products and recreational opportunities for southern than northern Ontarians. Regardless, the study demonstrates the importance of considering region-specific parameter estimates (i.e., spatial heterogeneity) when examining NIPF landowners. This fact maybe especially important when examining regional differences among Canadian NIPF landowners.

Issues such as an ageing population of landowners and increases to the number of absentee landowners are important for a variety of land management reasons. However, these characteristics appeared to have little influence on the willingness of landowners to consider conducting logging and to permit hunting. Age was related to the willingness of landowners to consider conducting logging, but the non-linear relationship provided a much different finding than most past studies (Binkley 1981, Kuuluvainen and Salo 1991, Kuuluvainen et al.1996, Kline et al. 2000).

Several limitations of this study are important for readers to consider. First, the willingness of a landowner to consider con- ducting forest harvesting should include market information related to generation of expected revenues from timber sales. By omitting such important economic variables, this study provides an incomplete analysis of the reasons why landowners decide to consider harvesting forests. Second, the examination of landowners' decisions to consider permitting hunting was overly simplistic and likely masks some important differences between landowners. Wright et al. (1988) argued that the decisions of landowners to permit hunting are not dichotomous. Instead, they contend that access falls along a continuum that includes prohibitive, exclusive, restrictive and open conditions. This study simplified the considerations of landowners into a dichotomy of either considering or not considering hunting on their lands. A more fruitful approach would embrace the ordinal nature of multiple access decisions to yield additional insights into determining the decisions of landowners to permit hunting. Third, this study focused on willingness to consider permitting various behaviours rather than actual behaviours. Although this focus allows the study to investigate the possibilities of expanding NIPF lands for recreational and forest harvesting pursuits, one may question the direct link between these considerations and actual behavioural choices. Fourth, the study only applies to NIPF landowners who own greater than 20 ha. It is quite possible that the NIPF landowners who hold smaller landholdings may differ in their propensity to permit various activities on their lands. Future studies of Canadian NIPF landowners should be designed to capture some of these missing elements from this study.

\section{Acknowledgements}

I would like to thank Eric Boysen and two anonymous reviewers for their constructive comments, and Sarah Browne for preparing the figure and editing the text. I would also like to thank Ontario Ministry of Natural Resources and many other project partners for contributing to the data collection and printing costs.

\section{References}

Binkley, C.S. 1981. Timber supply from private forests. Bulletin No. 92. School of Forestry and Environmental Studies, Yale University: New Haven. 97 p.

Boyd, R. 1984. Government support of nonindustrial production: the case of private forests, South. Econ. J. 51: 89-107.

Brunson, M.W., D.T. Yarrow, S.D. Roberts, D.C. Jr. Guynn and M.R. Kuhns. 1996. Nonindustrial private forest owners and ecosystem management: can they work together? J. For. 94(6): 14-21.

DeCoster, L.A, 1998. The boom in forest owners - a bust for forestry. J. For. 96(5): 25-28.

Dennis, D.F. 1989. An economic analysis of harvest behavior: integrating forest and ownership characteristics. For. Sci. 35(4): 1088-1104.

Environics. 2000. Survey of farmers, ranchers and rural landowners: attitudes and behaviours regarding land stewardship. Environics, Toronto, ON. 68 p.

Environics. 2001. Survey of rural landowners in Ontario, phase II: attitudes and behaviours regarding land stewardship. Environics, Toronto, ON. 66 p.

Factor Research Group. 1995. Rural landowner survey: final report. $46 \mathrm{p}$.

Fox, J. 1984. Statistical models and related methods: with applications to social research. John Wiley \& Sons, Toronto, ON. 449 p.

Hyberg, B.T. and D.M. Holthausen. 1989. The behavior of nonindustrial private forest landowners. Can. J. For. Res. 19: 1014-1023. 
Kline, J.D., R.J. Alig and R.L. Johnson. 2000. Fostering the production of nontimber services among forest owners with heterogeneous objectives. For. Sci. 46(2): 302-311.

Kuuluvainen, J., H. Karpinnen and V. Ovaskainen. 1996. Landowner objectives and nonindustrial timber supply. For. Sci. 42(3): 300-309.

Kuuluvainen, J. and J. Salo. 1991. Timber supply and life cycle harvest of nonindustrial private forest owners: an empirical analysis of the Finnish case. For. Sci. 37(4): 1011-1029.

Ontario Ministry of Natural Resources. no date. Rural lands and landowners of southern Ontario. Queen's Printer for Ontario, Toronto, ON. 70 p.

Ontario Ministry of Natural Resources. 2000. Annual report on forest management 1998/1999. Queen's Printer for Ontario, Toronto, ON. 102 p.

Prestemon, J.P. and D.N. Wear. 2000. Linking harvest choices to timber supply. For. Sci. 46(3): 377-389.

Row, C. 1978. Economies of tract size in timber growing. J. For. 80 576-583.

Royer, J.P. 1987. Determinants of reforestation behavior among southern landowners. For. Sci. 33(3): 654-667.

Salkie, F.J., M.K. Luckert and W.E. Phillips. 1995. An economic analysis of landowner propensity for management and harvesting in northwestern Saskatchewan. For. Chron. 71(4): 451-458.
Smyth, J.H. and I.A. Nausedas. 1982. Rural lands and landowners of Ontario: a private land forestry perspective. Environment Canada, Canadian Forestry Service and Ontario Ministry of Natural Resources. 97 p.

Thompson, R.P. and J.G. Jones. 1981. Classifying nonindustrial private forestland by tract size. J. For. 81: 288-291.

Tyson, C.B., S.H. Broderick and L.B. Snyder. 1998. A social marketing approach to landowner education. J. For. 96(2): 34-40.

United Nations Framework Convention on Climate Change (UNFCCC). 1997. Kyoto Protocol to the United Nations Framework on Climate Change. UNFCCC Document FCCC/CP/1997/7/Add.1. $60 \mathrm{p}$.

Wellstead, A.W., M. P. Brown and D.D. MacFarlane. 1999. Exploring woodlot owner managing and marketing decisions: Implications for Nova Scotia forest policy. For. Chron. 75(1) 87-91.

Wright, B.A, H.K. Cordell and T.L. Brown. 1990. Public recreational access: a national study of policies and practices of private landowners. In J. Vining (ed.). Social Science and Natural Resource Recreation Management. pp. 181-198. Westview Press, Boulder, CO. $330 \mathrm{p}$.

Wright, B.A, R.A. Kaiser and J.E. Fletcher. 1988. Hunter access decisions by rural landowners: an east Texas example, Wild. Soc. Bull. 16: $152-158$. 